\title{
Strategy Selection in the Universities via Fuzzy AHP Method:
}

\author{
A Case Study \\ Ömür Hakan Kuzu ${ }^{1}$ \\ ${ }^{1}$ Beysehir Ali Akkanat Faculty of Tourism, Selcuk University, Konya, Turkey \\ Correspondence: Ömür Hakan Kuzu, Beysehir Ali Akkanat Faculty of Tourism, Selcuk University, 42700, Konya, \\ Turkey. E-mail: ohkuzu@ selcuk.edu.tr
}

Received: December 5, 2019

Accepted: December 27, 2019

Online Published: January 7, 2020

doi:10.5430/ijhe.v9n2p107

URL: https://doi.org/10.5430/ijhe.v9n2p107

\begin{abstract}
SWOT (Strength, Weakness, Opportunity and Threat) Analysis, even though it enables analyzing the internal and external environment that is effective in the process of organizations and institutions to make strategic decision, is a method that has some deficiencies in terms of measurement and assessment. In order to eliminate the deficiencies of interests and make assessment through more exact data in the process of decision making, in literature, various methods under the title of quantitative SWOT Analysis has been used. One of these methods is to integrate SWOT analysis with Fuzzy Analytical Hierarchy Process (FAHP) method. In this study, the data of SWOT analysis were turned into a hierarchical structure and the model formed was solved by means of method of FAHP. The application of method was performed on the problem of strategy selection of a state university in Turkey. Surveys conducted among 1292 academic staff in the university were evaluated by SWOT analysis. For the 6 main strategies and 13 sub-strategies obtained as a result of the analyses, pairwise comparison surveys were conducted with 37 senior managers of the university. Questionnaires were analyzed by FAHP method and it was concluded that the most important strategy for the university is "to be in the country's top 5 universities and in the world's top 500 universities".
\end{abstract}

Keywords: fuzzy AHP, university, strategy selection

\section{Introduction}

Restructuring in higher education is the interaction of opportunities and threats. These opportunities and threats; emerged as a result of globalization, the increasing importance of information power in the economy and developments in communication. This has led to the reshaping of competition and the development of new models in universities. In this structuring process of the universities, it is referred to the third mission of the universities. This reference is to consider the demands of public and private sector and society in the first (education), second (research) mission, and management of universities (Salmi, 2002).

Foremost among these demands are increasing demand for higher education in every age group and status, more contribution to regional and national development, focusing on quality, tend to autonomous, transparent, flexible and accountable governance, need to performance management and strategic planning (Nohutcu, 2006).

These demands have been reshaping the universities for three decades. The projection of these elements in the 21st century university occurs such as contractor change in student fees, contributing to individual career planning, student-focused and lifelong learning and flexible structuring. Herewith massification, academic expansion, relevance, social dimension, accountability and financial re-structuring have become the issues of the higher education systems of the countries (Duderstadt, 2000; Duderstadt and Wulf, 2002).

In the face of these developments, universities had to take into account the following parameters when determining their mission and vision (Hayward and Ncayiyana, 2011):

$>$ Employment rate of university graduates

$>$ Which areas of science are more successful (centers of excellence)

$>$ Satisfaction of graduates from departments

$>$ Preparing students for business life 
$>$ Quality of faculty and university publications

$>$ Indexed publication status of academic staff

$>$ The rating of the university in national and international rankings

$>$ National and international recognition of academic staff

$>$ Knowledge and project production level

$>$ National and international award

$>$ Ability of reflecting the vision and mission of the university

At this point, it appears that a successful strategic planning, in which the vision, mission and objectives are handled with a holistic approach, should emphasize stakeholder participation and internationalization at every point. It is also thought that such an axis may enable the transformation of higher education values into opportunities in universities.

In the process of change mentioned above, sub-processes of strategic planning process can be listed as follows (Hayward and Ncayiyana, 2011):

$1^{\text {st }}$ step : Initial stage of strategic planning

$2^{\text {nd }}$ step $\quad$ : Strategic planning committee stage

$3^{\text {rd }}$ step $\quad$ : Determination of institutional values, vision and mission

$4^{\text {th }}$ step $\quad$ : Environmental analysis (SWOT -Strength, Weakness, Opportunity and Threat- analysis) stage

$5^{\text {th }}$ step : Sequencing and prioritizing of the goals

$6^{\text {th }}$ step $\quad$ : Financial planning stage

$7^{\text {th }}$ step $\quad:$ Reporting process (facilitation of the process)

$8^{\text {th }}$ step : Stakeholder engagement to support the strategic plan

$9^{\text {th }}$ step $:$ Implementation and actualization of the strategic plan

$10^{\text {th }}$ step : Measurement of success and lessons learned (monitoring and evaluation)

In this study the fourth and fifth step of strategic planning is addressed via quantitative SWOT analysis methods in a case study. First, some literature is submitted about quantitative SWOT analysis also the Fuzzy AHP (FAHP). Second, an implication is carried out in a Turkish state university for determining the best mission and vision statement in terms of strategic planning via Fuzzy AHP method.

The subject of the study consists of the problem "to select the most suitable strategic target for the vision and mission of the university in terms of strategic planning" which is a problem of making decision with multiple criteria. In this context, the aim of the study, in the selection of the most suitable strategic target of the university, utilizing the quantitative SWOT analysis, is to assess the pre-determined strategic targets in the light of main and sub-criteria of SWOT for making the most suitable selection. The top managers in searching conference hold by the university determined alternative strategies. In this study, these alternatives were evaluated by using FAHP method which integrates both subjective and objective viewpoints. In this sense, the research questions are as follows:

- What are the strategic goals of the university in the view of the academic staff and senior managers?

- How can the best strategic goals of the university be determined via Fuzzy AHP method?

\section{Literature Review}

\subsection{Quantitative SWOT Analysis and Analytical Hierarchy Process (AHP)}

By means of applications of SWOT analysis, qualitative examinations can be realized whereas quantitative assessments such as the importance of factors according to each other, their prioritizing etc. cannot be achieved by only carrying out SWOT analysis. As a result of combining Analytical Hierarchy Process (AHP) method with SWOT analysis, a possibility emerges to make pairwise comparison of SWOT factors and to weigh them according to each other. In this way, the process of selecting the most suitable strategy for the organizations is based on more rational foundations.

In the literature, the history of studies conducted on this subject dates from the early 2000s. The first study was carried out by Kurtilla, Pesonen, Kangas, and Kajanus (2000) on the field of environment. Some of the other studies in the literature are summarized as following (Akdeniz, 2018; Arslan, 2010) in Table 1: 
Table 1. Literature review for quantitative SWOT analysis

\begin{tabular}{|c|c|c|}
\hline Author(s) & Field of Study & The Subject of Study \\
\hline Kurttila et al. (2000) & Environmental Science & Factor evaluation in forest planning \\
\hline Steward et al. (2002) & Data and Information & $\begin{array}{l}\text { Development of a strategic implementation } \\
\text { plan }\end{array}$ \\
\hline Kangas et al. (2003) & Environmental Science & To determine alternative strategies \\
\hline Kajanus et al. (2004) & Tourism & Factor evaluation in tourism planning \\
\hline Shrestha et al. (2004) & Agriculture & Factor evaluation in pasture determining \\
\hline Shinno et al. (2006) & Production Management & Factor evaluation in competitive analysis \\
\hline Masozera et al. (2006) & Environmental Science & Factor evaluation in forest planning \\
\hline Chou and Hsu (2008) (2008) & Business Administration & $\begin{array}{l}\text { Analysing a country's competitiveness in } \\
\text { terms of their technological human } \\
\text { resources }\end{array}$ \\
\hline Chamodrakas et al. (2010) & Business & $\begin{array}{l}\text { Supplier selection in electronic } \\
\text { marketplaces }\end{array}$ \\
\hline Nandi et al. (2011) & Engineering & $\begin{array}{l}\text { Using AHP method for construction project } \\
\text { selection }\end{array}$ \\
\hline Sikorová and Nytra (2013) & Business & $\begin{array}{l}\text { Implemantation of AHP method in service } \\
\text { quality management }\end{array}$ \\
\hline Gupta (2015) & Operations Management & $\begin{array}{l}\text { Selection of best hospital for surgery using } \\
\text { AHP }\end{array}$ \\
\hline Basset et al. (2018) & Operations Research & $\begin{array}{l}\text { Neutrosophic AHP incorporated with } \\
\text { SWOT analyis }\end{array}$ \\
\hline
\end{tabular}

When determining the institutional strategy by using SWOT solutions, the internal and external factors that are effective on strategy are listed roughly, indefinitely, and superficially and are evaluated qualitatively and insufficiently. Using the method of AHP under SWOT, which was developed by Thomas Saaty in 1971 (Wind and Saaty; 1980Saaty, 1990), the priority values of SWOT factors are numerically determined. This is provided by solving SWOT factors via the approach of processes of pairwise comparisons and of calculations of eigenvalue in the method of AHP. Thus, a new alternative strategy which states an existing or expected situation can be examined in detail (Gurbuz, 2010).

The stages of quantitative SWOT analysis can be put in order as follows in Figure 1:

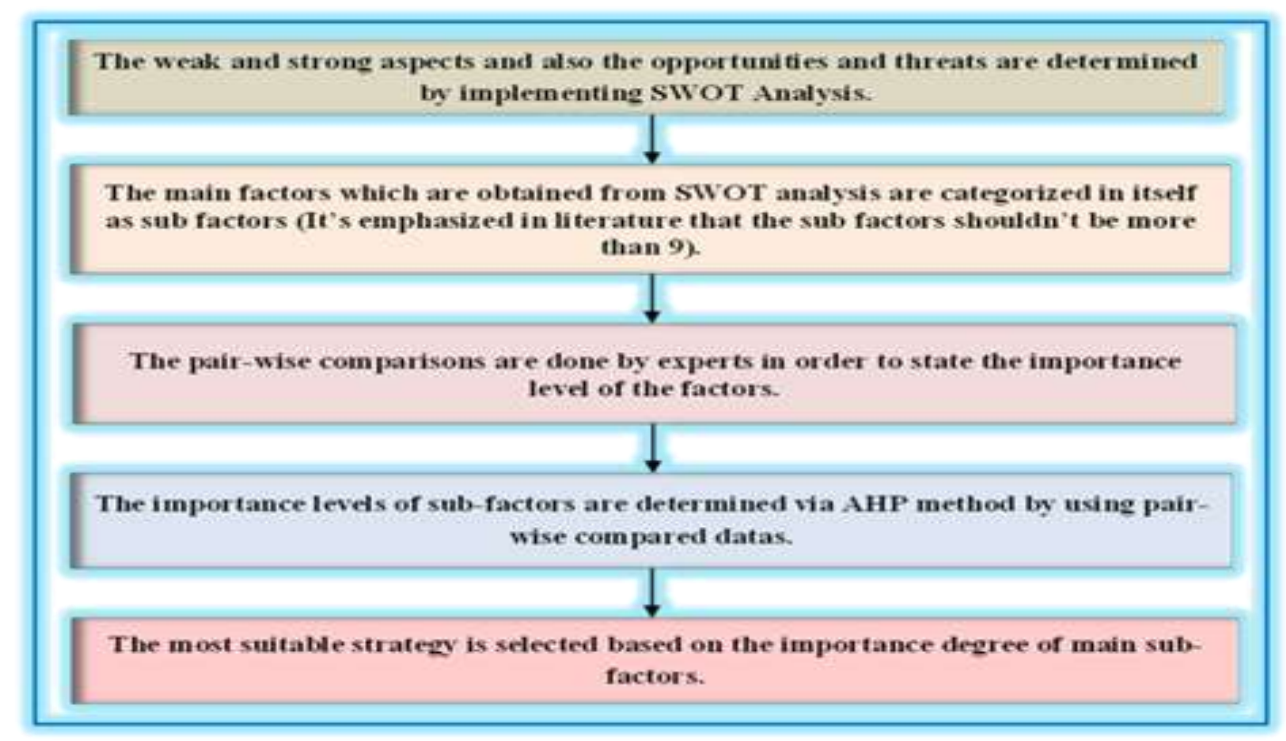

Figure 1. Process stages of quantitative SWOT analysis 


\subsection{Method of Fuzzy Analytical Hierarchy Process (FAHP)}

\subsubsection{FAHP at a Glance}

Even though AHP takes into consideration the knowledge of experts, it does not reflect the style of human thought (Kahraman, Cebeci, and Ulukan, 2003). In addition, it has been also criticized due to the fact that it is insufficient in the situations of ambiguity and instability in the process of pairwise comparison. Because of these reasons, in Fuzzy analytical hierarchy process (FAHP), unlike AHP in which the exact values are used, comparison rates are given in a range of values. Thus the issue of ambiguity is able to be coped with more easily in decision making process (Karakasoğlu, 2008).

In the literature, there are a lot of techniques of FAHP. These techniques are systematic approaches to the problems of alternative selection and justification, using the concepts of theory of fuzzy set. Decision makers find the interval scales reliable than fixed scales. The reason for this is that the decision makers are not certain about their views about a comparison evaluation because of its nature (Citli, 2006). Some of the methods developed in Fuzzy AHP are following:

Van Laarhoven and Pedrcyz (1983) compared the fuzzy rates, defined with triangular membership functions. By Van Laarhoven and Pedrycz (1983), a method was developed, which is the extension of classical AHP developed by Saaty (1971). In this model, the Fuzzy rates are compared, which are expressed with triangular Fuzzy numbers. Calculation steps are the same the method of AHP. The fuzzy weights and fuzzy performance values are obtained by using the method of least squares which is developed by Lootsma (Kahraman, Cebeci, and Ruan, 2004).

Buckley (1985) developed a new model by using trapezoidal fuzzy numbers. He used the rates of fuzzy comparison, another extension of the method of AHP, developed by Saaty (1971). In addition, he has drawn draw attention to the problems in the method of Van Laarhoven and Pedrycz (1983).

Chang (1996) used triangular fuzzy numbers for comparisons and suggested the method of expanding analysis for pairwise comparisons. In many problems, in which Fuzzy AHP was applied, expanded AHP method that was developed by Chang (1996). In this method, there is no need for sectional levels (Guner, 2005). This method, besides using the values of artificial degree, stands out with simple level ranking and composite total ranking. The most advantageous part for this method is that it has a calculation requirement and has no additional process except following the steps of AHP. It has a disadvantage is that it only uses the triangular fuzzy numbers (Durdudiler, 2006).

In many studies, method of AHP is used as a method to make a decision with multiple criteria. But, except for the quantitatively measurable criteria, subjectivity of the views of experts has been an advantage of method of AHP (Anderson, Sweeney, and Williams, 1998). As a result of subjectivity, the results digress from the certainty. In this condition, implementation of fuzzy AHP (FAHP) is preferred. Some FAHP implementations, compiled from Aydın (2009), Celik and Gok Kisa (2017), and related literature, are shown in Table 2: 
Table 2. FAHP literature review

\begin{tabular}{|c|c|}
\hline Author(s) & The subject of the study \\
\hline Carlsson and Walden (1995) & Selection of optimal location for the plant of ice hockey \\
\hline Yang and Lee (1997) & $\begin{array}{l}\text { Selecting the best location for a consultancy firm by forming a model } \\
\text { with four main criteria and two sub-criteria, under three alternatives }\end{array}$ \\
\hline Zhu, Jing and Chang (1999) & $\begin{array}{l}\text { Prospecting for oil in China by improving further the method of } \\
\text { Chang (1996) }\end{array}$ \\
\hline Csutora and Buckley (2001) & $\begin{array}{l}\text { Job selection criteria of new graduates by using the Lambda-Max } \\
\text { method }\end{array}$ \\
\hline Kwong and Bai (2002) & $\begin{array}{l}\text { Determination of customer demands and providing customer } \\
\text { satisfaction in terms of production planning }\end{array}$ \\
\hline Enea and Piazza (2004) & Project Selection by Constrained Fuzzy AHP \\
\hline $\begin{array}{l}\text { Mikhailov } \\
\text { and Tsvetino (2004) }\end{array}$ & Determination of the optimal service provider \\
\hline Xia and $\mathrm{Wu}(2007)$ & Supplier selection problems \\
\hline Jyoti and Deshmukh (2008) & Performance evaluation of national R\&D companies \\
\hline Chamodrakas and Martakos (2010) & Supplier selection problems \\
\hline Chou et al. (2012) & Evaluation of the criteria for human resource \\
\hline Kara and Cheikhrouhou (2014) & Selection criteria of software \\
\hline Chen et al. (2015) & Evaluation of education performance \\
\hline Dayanandan and Kalimuthu (2018) & $\begin{array}{l}\text { Evaluation of Buckley method in terms of the influence of } \\
\text { maintainability in software quality }\end{array}$ \\
\hline
\end{tabular}

\subsubsection{Method of Geometrical Mean of Buckley (1985)}

The method of geometrical mean, developed by Buckley (1985), is a method, which uses linguistic variables for expanding AHP. The levels of pairwise comparisons of linguistic variables and related membership functions are shown in Table 3:

Table 1. FAHP linguistic variable scale

\begin{tabular}{|c|c|c|c|}
\hline $\begin{array}{l}\text { Fuzzy } \\
\text { Number } \\
\text { Scale }\end{array}$ & $\begin{array}{l}\text { Identification of the } \\
\text { Linguistic Variables }\end{array}$ & $\begin{array}{l}\text { Fuzzification } \\
\text { Number }\end{array}$ & User Identification \\
\hline 1 & Equal importance & $(\mathrm{L}, \mathrm{M}, \mathrm{U})$ & $(1,1,1)$ \\
\hline 3 & Moderate importance & $(\mathrm{L}, \mathrm{M}, \mathrm{U})$ & $(2,3,4)$ \\
\hline 5 & Strong importance & $(\mathrm{L}, \mathrm{M}, \mathrm{U})$ & $(4,5,6)$ \\
\hline 7 & Very strong importance & $(\mathrm{L}, \mathrm{M}, \mathrm{U})$ & $(6,7,8)$ \\
\hline 9 & Extreme importance & $(\mathrm{L}, \mathrm{M}, \mathrm{U})$ & $(7,8,9)$ \\
\hline $2,4,6,8$ & Intermediate values & $(\mathrm{L}, \mathrm{M}, \mathrm{U})$ & $\begin{array}{l}(-,-,-) \\
\text { User-Defined }\end{array}$ \\
\hline
\end{tabular}

Fuzzy pairwise comparison matrix related with data obtained by using membership functions in Table 3 is given in the form of

Where,

$$
A=\left[\begin{array}{ccc}
\widetilde{a_{11}} & \cdots & \widetilde{a_{\text {ln }}} \\
\vdots & \ddots & \vdots \\
\widetilde{a_{n 1}} & \cdots & \widetilde{a_{m n}}
\end{array}\right]
$$

$$
\widetilde{a_{\imath j}} * \widetilde{a_{\jmath l}} \approx 1 \text { and } \widetilde{a_{\imath j}} \cong w_{i} / w_{j}
$$

In order to fuzzy weights of each criterion to find, in algorithm of geometric mean method, 


$$
\widetilde{r_{l}}=\left(\widetilde{a_{l 1}} * \widetilde{a_{l 2}} * \ldots * \widetilde{a_{l n}}\right)^{1 / n}
$$

As weight of each criteria, is calculated from

$$
\widetilde{w_{l}}=\widetilde{r_{l}} *\left(\widetilde{r_{1}} \oplus \widetilde{r_{2}} \oplus \ldots \oplus \widetilde{r_{n}}\right)^{-1}
$$

Here, provided that as

$\left.\widetilde{r_{k}}=\left(l_{k}, m_{k}, u_{k}\right) \quad \widetilde{\left(r_{k}\right.}\right)^{-1}=\left(1 / u_{k} 1 / m_{k} 1 / l_{k}\right)$ and $*$ shows fuzzy multiplication, $\oplus$ fuzzy addition operation also.

\section{Method}

\subsection{Research Design}

This study is designed using a case study model, one of the qualitative research models, to determine the best strategy in the strategic planning process in a state university. A case study is used for exploring the complexity or a particular project, policy, institution or system in a real life in depth (Simons, 2009). In this study, the case study design is preferred because it is aimed to determine the best strategy for 2014-2018 Strategic Plan of a state university in Turkey.

\subsection{Participants}

Purposeful sampling approach (Mason, 2002; Patton, 2002), which is an effective method, was preferred to make the information more comprehensive and detailed. The research is made at a Turkish state university, the second largest university from the point of the number of students over 80.000 and on top ten ranking in terms of faculty members over 2.500. A total of 2,680 academic staff working in the university constitutes the universe of this study. As a result of a questionnaire which included 1,292 academic staff, 27 of which were invalid, a second questionnaire was applied to 37 senior managers (rector, vice-rector, rector consultant, dean, department head, etc.) selected among these academic staff. The data in this study were obtained from 37 experts and managers of the university.

\subsection{Data Collection Tools}

The questionnaire used in the study is compiled from the studies (Hayward and Ncayiyana, 2011; Kadir, 2012; Nickel, 2011; Stukalina, 2014). After conducting a 9 point Likert scale questionnaire, which consists of national and international trends in the context of higher education re-structuring (20 questions), the positive or negative and weaknesses aspects of the university based on historical development of the university and new currents (32 questions) and strategic positioning (17 questions), the sub-factors and main strategies were determined by using SWOT analysis. These strategies were evaluated in a 9 point Likert scale questionnaire set by 37 academic staff.

\subsection{Data analysis}

In this study, Fuzzy analytical hierarchy process was applied via the geometrical mean method of Buckley for determining the best strategy of the university. First, alternative strategies, determined in searching conference of the university, were evaluated in the context of the main and sub-criteria of SWOT analysis. Second a survey was conducted on the managers of units in the university for pairwise comparisons of the criteria and strategies.

The data obtained from 37 participants were made fuzzy, using fuzzy number scales associated with linguistic variables. Then, applying the Fuzzy arithmetical operations, the geometrical mean of survey data on each variable was taken and the new Fuzzy values obtained constituted the pairwise comparison matrix. Each comparison matrix was assessed according to the geometrical mean method of Buckley and the Fuzzy weights obtained were made clear according to the center of gravity method. Finally, the clarified values were obtained which give the importance level in the context of criteria of each strategy.

In sum the process of decision support (data analysis) on the study can be summarized as follows:

i. Determining the main strategic targets by means of SWOT analysis in Searching Conference of the university

ii. Determining the main and sub-criteria which are important for the future of the university

iii. Forming the model of the study

iv. Forming FAHP comparison surveys

v. Making pairwise comparisons with the top managers/their assistants of the departments

vi. Fuzzification of data from comparison surveys

vii. Taking the geometrical mean of fuzzy data and determining the fuzzy counterparts of each criterion

viii. Determining the weights of criteria by means of comparison matrix and method of Buckley 
ix. Determining the most suitable strategic goals

\section{Results}

Initially, the hierarchy (the main and sub-criteria) was formed (as shown in Figure 2) for selecting the most suitable strategic goal for the university. In virtue of the hierarchy, FAHP comparisons and calculations were made. After forming the hierarchic structure, as a requirement of the structure of FAHP, the main and sub-criteria were compared to each other orderly. The comparisons of the criteria are shown in Table 4:

Table 4. Fuzzy Pairwise Comparison Matrix of Main Criteria

\begin{tabular}{ccccc} 
& Threats & Opportunities & Strengths & Weaknesses \\
\hline Threats & $(1.00,1.00,1.00)$ & $(0.28,0.33,0.40)$ & $(0.25,0.29,0.35)$ & $(0.46,0.55,0.67)$ \\
Opportunities & $(2.50,3.03,3.57)$ & $(1.00,1.00,1.00)$ & $(0.53,0.62,0.74)$ & $(1.55,1.91,2.31)$ \\
Strengths & $(2.86,3.45,4.00)$ & $(1.35,1.61,1.89)$ & $(1.00,1.00,1.00)$ & $(2.18,2.68,3.18)$ \\
Weaknesses & $(1.49,1.82,2.17)$ & $(0.43,0.52,0.65)$ & $(0.31,0.37,0.46)$ & $(1.00,1.00,1.00)$
\end{tabular}

After comparisons of the criteria the fuzzy weights were calculated for each criterion by using the criteria taking place in pairwise comparison matrix of main criteria via equation 4. As it is shown in Figure 2, the weights were found as threats $(0.08,0.10,0.14)$, opportunities $(0.23,0.30,0.39)$, strengths $(0.33,0.43,0.55)$, and weakness $(0.13$, $0.17,0.22)$ :

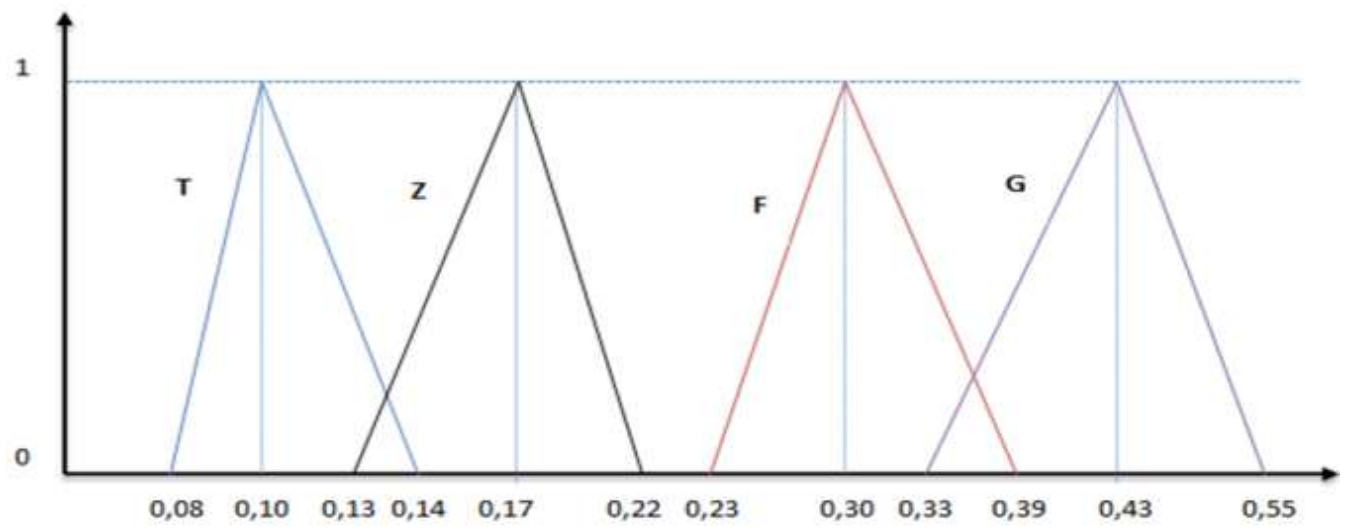

Figure 2. Triangular fuzzy weights of main criteria

Looking at the fuzzy weights of the main criteria, it is shown that the largest range is the strengths as main criteria. Accordingly, among the relevant criteria, it can be said that the most significance ranks as strengths. When these fuzzy values are narrowed, the importance levels of the criteria also confirm this inference as it is shown in Table 5:

Table 5. The weights of alternatives (strategies) according to main criteria

\begin{tabular}{cccccc} 
& Threats & Opportunities & Strengths & Weaknesses & $\begin{array}{c}\text { General } \\
\text { Importance Level }\end{array}$ \\
$\begin{array}{c}\text { Importance Level } \\
\text { of Main Criteria }\end{array}$ & 0,1079 & 0,3073 & 0,4358 & 0,1735 & 0,0565 \\
S1 & 0,0444 & 0,0461 & 0,0584 & 0,0696 & 0,0971 \\
S2 & 0,0891 & 0,0853 & 0,0963 & 0,1113 & 0,1526 \\
S3 & 0,1600 & 0,1477 & 0,1362 & 0,1766 & 0,3488 \\
S4 & 0,3251 & 0,3594 & 0,3358 & 0,3284 & 0,1625 \\
S5 & 0,1528 & 0,1543 & 0,1616 & 0,1623 & 0,2325 \\
S6 & 0,2488 & 0,2293 & 0,2370 & 0,1838 & \\
\hline
\end{tabular}


The importance levels for 13 sub criteria calculated according to the Fuzzy AHP method of Buckley are shown in Table 6:

Table 6. The weights of alternatives (strategies) according to the sub-criteria

\begin{tabular}{lcccccc} 
Sub-criteria & $\mathrm{S} 1$ & $\mathrm{~S} 2$ & $\mathrm{~S} 3$ & $\mathrm{~S} 4$ & $\mathrm{~S} 5$ & $\mathrm{~S} 6$ \\
\hline Competition & 0,0398 & 0,081 & 0,1449 & 0,3742 & 0,1593 & 0,2232 \\
Requirement of qualified human resources & 0,049 & 0,0867 & 0,1444 & 0,3874 & 0,1373 & 0,2177 \\
The business world and social changes & 0,0451 & 0,0876 & 0,1354 & 0,3118 & 0,226 & 0,2137 \\
Being stakeholder and student-centered & 0,057 & 0,1079 & 0,1393 & 0,362 & 0,1561 & 0,2077 \\
University and industry cooperation & 0,0495 & 0,0896 & 0,1442 & 0,2856 & 0,2788 & 0,1749 \\
Institutional identitiy & 0,0718 & 0,1099 & 0,1687 & 0,3622 & 0,1412 & 0,1741 \\
Education & 0,0682 & 0,1013 & 0,1521 & 0,3333 & 0,1516 & 0,2189 \\
Geographical location and infrastructure & 0,081 & 0,1307 & 0,1431 & 0,3265 & 0,1614 & 0,1865 \\
Innovation, R\&D and cooperation & 0,0476 & 0,0781 & 0,1668 & 0,2838 & 0,2075 & 0,2404 \\
Focused on horizontal developing & 0,104 & 0,1484 & 0,1717 & 0,3043 & 0,1543 & 0,1541 \\
Strategic planning deficiencies & 0,0867 & 0,1332 & 0,1676 & 0,3116 & 0,1558 & 0,1736 \\
Talented human resources deficiencies & 0,0773 & 0,1262 & 0,1506 & 0,2894 & 0,1792 & 0,2137 \\
International cooperation and relations with business & 0,0525 & 0,09 & 0,1488 & 0,293 & 0,2034 & 0,2386
\end{tabular}

Figure 3 shows the ranges of the main criteria weights in terms of importance levels in a graph:

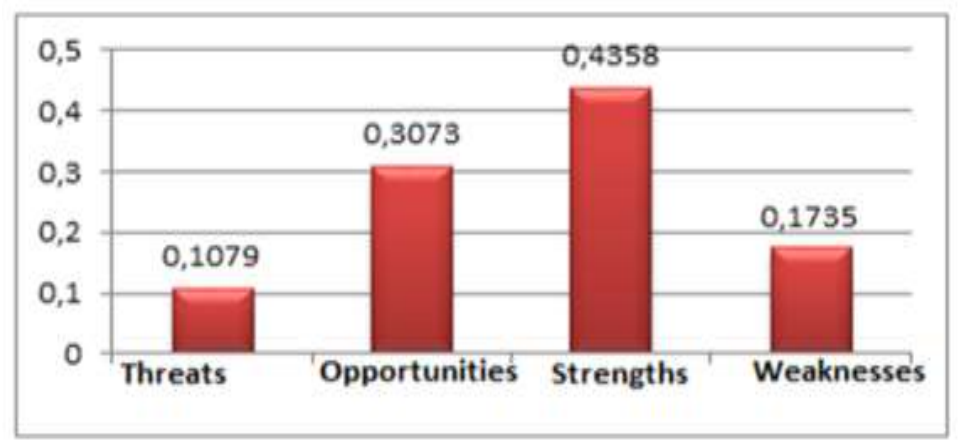

Figure 3. The importance levels of main criteria according to the method of FAHP

In addition Figure 4 shows the general weights of alternatives (strategies) in a graph:

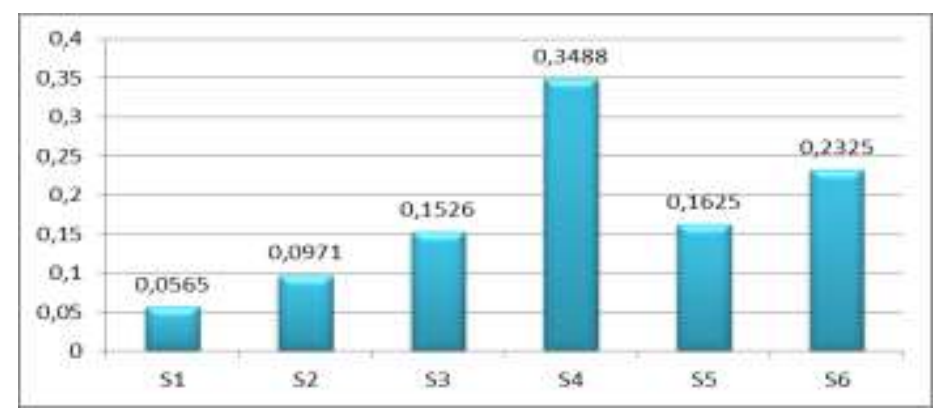

Figure 4. The general weigts of strategies according to the geometrical mean method of Buckley 
As a consequence, ranking of the strategies is as below:

1. S4: To be in the country's top 5 universities and in the world's top 500 universities

2. S6: To make joint ventures with world-class universities

3. S5: To develop collaboration between industry and university

4. S3: To be the most entrepreneurial and innovative university in the country

5. S2: To be a leader among the regional universities

6. S1: To be the most prefered university in the city

\section{Discussion \& Conclusion}

In today's fierce competition environment, universities should provide competitive advantage over their competitors by eliminating the uncertainties in global competition conditions and environment as much as possible. This is also a conflict in terms of finding balance between their mission demands and changing values of the higher education systems induced by external factors (Scott, 2006). In this process, universities have entered a process of mission expansion in the sphere of state policies, market conditions and social expectations (Gallagher, 2011).

The main social expectations such as instrumentalist purpose of the state and consumerist interests of students (Gallagher, 2011) have enlarged the role of the universities in the societies. So making the right strategic choice has come to the forefront for the universities. This choice is based on the history of the institution, strengths and weakness aspects, image, connections with external partners and geographical location of the universities (Rojas and Bernasconi, 2011) and it is difficult to choose the right strategy among all these determinants. It shows that in order to choose the most suitable strategy, they have to support their management decisions with systematic assessment (Hayward and Ncayiyana, 2011). Obviously, it would be more beneficial to make these evaluations with scientific methods.

In this study, a quantitative SWOT analysis method was used to facilitate the decision processes of the managers and provide an objective perspective in this process. According to the results from implementation of FAHP method, when all main criteria and sub-criteria are taken into consideration (as is seen Table 5 and 6), global weights of alternative strategies show the importance levels of the university in the present situation. In this case, for the future of the university, it can be said that the most important strategy is to be in the country's top 5 universities and in the world's top 500 universities (S4). The second most important strategy for the university is to make joint ventures with world-class universities (S6). The results show that being a world-class university is the basic and unique issue for the university. Although this result is described as a paradox, all universities want to be member of the exclusive group of world-class universities (Altbach, 2004).

On the other hand, the third most important strategy for the university, to develop collaboration between industry and university (S5), is accepted both a central position of national innovation system and paradoxical status for the industry and university (Barré, 2007). This collaboration is seen an effective respond for the demands of knowledge-based economy and needs of new governance systems such as associational and joined-up governance (Wolfe, 2007).

The main limitation of this study is that only the opinions of academic staff are taken into consideration when determining the most appropriate strategy for the university. However, internal and external stakeholders should be involved in the strategy determination process of the universities. In addition, it is recommended that different quantitative and qualitative methods should be used together in the strategy selection process of the universities. Finally, more accurate results can be achieved by making comparisons using a number of quantitative SWOT analysis methods.

\section{References}

Akdeniz, E (2018). Selecting the best employee in an organization by using AHP method: A review of an organization in IT sector. Journal of Suleyman Demirel University Institute of Social Sciences, 31(2), 61-90. Retrieved from http://sbedergi.sdu.edu.tr/assets/uploads/sites/343/files/2018-3-09112018.pdf

Altbach, PG (2015). The costs and benefits of world-class universities. International Higher Education, (33), 5-8. https://doi.org/10.6017/ihe.2003.33.7381

Anderson, DR., Sweeney, DJ., Williams, TA (1998). Quantitative methods for business (7th ed.). Ohio: South-Western College Pub. 
Arslan, ET (2010). Strategy selection by analytical hierarchy process: An application in Suleyman Demirel University, Faculty of Economics and Administrative Sciences. The Journal of Suleyman Demirel University Faculty of Economics and Administrative Sciences, 15 (2), 455-477.

Aydın, O (2009). Hospital Location for Ankara with Fuzzy AHP. Dokuz Eylul University Faculty of Economics and Administrative Sciences Journal, 24(2), 87-104. Retrieved from https://iibfdergi.deu.edu.tr/index.php/cilt1-sayi1/article/view/260/pdf_240

Barré, R (2007). UIL-related policies of national governments: A synthetic view. In S. Yusuf, and K. Nabeshima (Eds.), How universities promote economic growth (pp. 111-115). Washington DC: The International Bank for Reconstruction and Development/The World Bank. https://doi.org/10.3138/9781442684690

Buckley, JJ (1985). Fuzzy hierarchical analysis. Fuzzy Sets and Systems, 17(3), 233-247. https://doi.org/10.1016/0165-0114(85)90090-9

Chang, DY (1996). Applications of the extent analysis method on fuzzy AHP. European Journal of Operational Research, 95(3), 649-655. https://doi.org/10.1016/0377-2217(95)00300-2

Celik P., Gok Kisa AC (2017). Fuzzy AHP-Fuzzy PROMETHEE approach in evaluation of e-service quality: Case of airline web sites. The Journal of International Social Research, 10(52), 1003-1013. https://doi.org/10.17719/jisr.2017.1954

Citli, N (2006). Fuzzy Multi Criteria Decision Making. Unpublished M. Sc. Thesis, Yildiz Technical University, İstanbul, Turkey.

Duderstadt, JJ (2000). A university for the 21st century. Ann Arbor: University of Michigan Press. https://doi.org/10.3998/mpub.16836

Duderstadt, JJ, Wulf, W (Eds.). (2002). The impact of information technology on the future of the research university. Washington, D.C.: National Academy Press.

Durdudiler, M (2006). A supplier performance assessment application in retail using AHP and fuzzy AHP. Unpublished M. Sc. Thesis, Yildiz Technical University, İstanbul, Turkey.

Gallagher, M (2011). The role of elite universities in national higher education and research systems, and the challenges of prosecuting the case for concentrating public investment in their development in Australia, In N. C. Liu, Q. Wang, and Y. Cheng (Eds.), Paths to a world-class university (pp. 29-66). Rotterdam: Sense Publishers.

Guner, H (2005). Fuzzy AHP and the application for a company's supplier selection problem, Unpublished M. Sc. Thesis, Pamukkale University, Denizli, Turkey.

Gurbuz, F (2010). A'WOT analysis-application on department of industrial engineering of Erciyes University. Erciyes University Journal of Institute of Science and Technology, 26(4), 369-378. Retrieved from https://dergipark.org.tr/en/pub/erciyesfen/issue/25572/269753

Hayward, FM, Ncayiyana, DJ (2011). Strategic planning for higher education, In Philip G. Altbach (Ed.), Leadership for world-class universities: Challenges for developing countries (pp. 8-32). New York: Routledge.

Kadir, NZHA (2012). Strategy management process in higher education: A case study on a Malaysian public university. Unpublished doctoral dissertation, University of East Anglia, Malaysia.

Kahraman, C, Cebeci, U, Ruan, D (2004). Multi-attribute comparison of catering service companies using fuzzy AHP: The case of Turkey. International Journal of Production Economics, 87(2), 171-184. 10.1016/S0925-5273(03)00099-9

Kahraman, C, Cebeci U, Ulukan Z (2003). Multi-criteria supplier selection using fuzzy AHP. Logistics Information Management, 16(6), 382-394. https://doi.org/10.1108/09576050310503367

Karakasoğlu, N (2008). Fuzzy multi-criteria decision making methods and application. Unpublished M. Sc. Thesis, Pamukkale University, Denizli, Turkey.

Kurttila, M, Pesonen, M Kangas, J, Kajanus, M (2000). Utilizing the analytic hierarchy process (AHP) in swot analysis-a hybrid method and its application to a forest-certification case. Forest Policy and Economics, 1(1), 41-52. https://doi.org/10.1016/S1389-9341(99)00004-0

Mason, J (2002). Qualitative researching. London: Sage. 
Nickel, S (2011). Strategic management in higher education institutions-approaches processes and tools. Retrieved from https://www.researchgate.net/publication/261020107_Strategic_Management_in_Higher_Education_Institution s_-_Approaches_Processes_and_Tools.

Nohutcu, A (2006). Restructuring and management of higher education institutions in knowledge society: Major trends, developments and the bologna process. Journal of Knowledge Economy \& Knowledge Management, I(I-II), 50-66. Retrieved from https://dergipark.org.tr/tr/pub/beyder/issue/3485/47394

Patton, MQ. (2002). Qualitative research ve evaluation methods. Thousand Oaks, CA: Sage. https://doi.org/10.4135/9781446268322

Rojas, A, Bernasconi, A (2011). Governing universities in times of uncertainty and change. In P. G. Altbach (Ed.), Leadership for world-class universities: Challenges for developing countries (pp. 33-51). New York: Routledge.

Saaty, TL (1990). How to make a decision. The analytic hieararchy process. European Journal of Operational Research, 48, 9-26. https://doi.org/10.1016/0377-2217(90)90057-I

Salmi, J (2002). Facing the challenges of the twenty-first century. Perspectives: Policy and Practice in Higher Education, 6(1), 8-12. https://doi.org/10.1080/13603100120118959

Scott, JC (2006). The mission of the university: Medieval to postmodern transformation. Journal of Higher Education, 77(1), 1-39. https://doi.org/10.1080/00221546.2006.11778917

Simons, H (2009). Case study research in practice. London: Sage.

Stukalina, Y (2014) Strategic management of higher education institutions. Management of Organizations: Systematic Research, 70, 79-90. https://doi.org/10.7220/MOSR.1392.1142.2014.70.6

Van Laarhoven, PJM, Pedrycz, W (1983) A fuzzy extension of Saaty's priority theory. Fuzzy Sets and Systems, 11(1-3): 229-241. https://doi.org/10.1016/S0165-0114(83)80082-7

Wind, Y, Saaty, TL (1980). Marketing applications of the analytic hierarchy process. Management Science, 26(7), 641-658. https://doi.org/10.1287/mnsc.26.7.641

Wolfe, DA (2007). The role of higher education and new forms of governance in economic development: The Ontario case. In S. Yusuf, and K. Nabeshima (Eds.), How universities promote economic growth (pp. 119-138). Washington DC: The International Bank for Reconstruction and Development/The World Bank. 